\title{
Seasonal changes in scrotal circumference, the quantity and quality of ram semen in Hungary
}

János Oláh, Szilvia Kusza, Sándor Harangi, János Posta, András Kovács, Anna Pécsi, Csilla Budai and András Jávor

Institute of Animal Husbandry, University Debrecen, Debrecen, Hungary

\begin{abstract}
In this study, the quantitative and qualitative traits of semen were studied in seven rams of different breeds (Prolific Merino, Cokanski Tsigai, Barbados Blackbelly, Bábolna Tetra, Awassi, Ile de France and Suffolk), bred in Hungary. The semen parameters (density, volume, $\mathrm{pH}$, mass motility, \% motility, thawing and heat resistance), freezability of semen and the factors influencing these parameters were evaluated with respect to breed and season. The fresh and post-thawing quality of semen varied greatly with the breed and the season. The postthawing motility of semen cells was outstandingly high for Awassi rams in three seasons. During the test period, the smallest scrotal circumference was measured for Barbados Blackbelly, except for the summer when it increased by $12.5 \mathrm{~cm}$. The reintroduction of artificial insemination could lead to a significant advancement of the sheep sector in Hungary. To promote this, we have provided useful and new information for breeders and organisations.
\end{abstract}

Keywords: rams, season, semen characteristics, scrotal circumference

\section{Introduction}

Artificial insemination is probably the most important technique to reach genetic improvement in animals (Salamon \& Maxwell 2000).

When evaluating sperm quality, the motility of sperm is described most frequently by the subjectively determined motility (Söderquist et al. 1991, Januskauskas et al. 2000). In some cases, good motility is accompanied by low fertility, but poor motility always goes together with low fertility. However, there are numerous other parameters such as the ratio of viable sperm, computer-estimated motility and acrosome integrity which show a significant correlation with fertility (Zhang et al. 1998).

Archiv Tierzucht 56 (2013) 10, 102-108

doi: $10.7482 / 0003-9438-56-010$

Corresponding author:

Szilvia Kusza; email: kusza@agr.unideb.hu

Institute of Animal Husbandry, University Debrecen, H-4032 Debrecen, Böszörményi str 138, Hungary

() 2013 by the authors; licensee Leibniz Institute for Farm Animal Biology (FBN), Dummerstorf, Germany.

This is an Open Access article distributed under the terms and conditions of the Creative Commons Attribution 3.0 License (http://creativecommons.org/licenses/by/3.0/).
Received: 18 January 2012

Accepted: 4 July 2012

Online: 22 February 2013 
The reproduction ability of sheep is influenced by seasonal factors such as temperature, relative humidity and the number of sunny hours. Semen production and freezability are better in the autumn because the seasonal fluctuation in seminal plasma protein components (Dacheux et al. 1981, D'Alessandro \& Martemucci 2003). The daily volume of semen changes with the season in rams living north of $40^{\circ}$ latitude (Pelletier et al. 1988). They found seasonal differences in semen volume, motility, scrotal circumference and the testosterone level of the plasma; however, the semen was suitable for artificial insemination throughout the whole year. The best quality was found in the late summer-autumn period.

Considerable seasonal variation was found in scrotal circumference, sperms of normal morphology, libido and mating capacity in Suffolk, Lincoln, Columbia and Polypay breeds on five rams per breed (Mickelsen et al. 1982). The average scrotal circumference was the largest from August until October and the smallest in February.

However there are several information about the characteristics of ram semen from different breeds, there has been no research on the semen characteristics of Suffolk, Ile de France, Bábolna Tetra, Prolific Merino, Barbados Blackbelly, Cokanski Tsigai and Awassi breeds under Hungarian climatic conditions. We assumed that there are great differences between the rams of different breeds and their suitability for semen production.

\section{Materials and methods}

The study was carried out at the three East-Hungarian farms (Bakonszeg: Awassi; Szendrő: Suffolk, Ile de France, Babolna Tetra; Debrecen: Prolific Merino, Cokanski Tsigai, Barbados Blackbelly).

Semen collection was performed once a week on 4 to 6 occasions per each season for each breed. One ejaculate per day was taken from rams trained for an artificial vagina, placed in groups separately for each breed. The rams in each group were of mixed age, including were young, middle-aged and older animals. The number of animals per breed and per season is shown in Table 1. Directly after the ejaculation, the fresh semen was evaluated, and volume, density, mass motility and percent motility were determined.

Table 1

Number of rams per breed and per season

\begin{tabular}{lcccc}
\hline & Autumn & Winter & Spring & Summer \\
\hline Awassi & 7 & 6 & 5 & 5 \\
Barbados Blackbelly & 7 & 7 & 7 & 7 \\
Bábolna Tetra & 7 & 11 & 10 & 12 \\
Ile de France & 11 & 11 & 11 & 17 \\
Prolific Merino & 7 & 7 & 7 & 7 \\
Suffolk & 9 & 8 & 8 & 9 \\
Tsigai & 11 & 12 & 8 & 9 \\
Total & 59 & 62 & 56 & 66 \\
\hline
\end{tabular}


Density, mass motility and percent motility were subjectively estimated based on traditional macroscopic and microscopic examinations. For judging mass, motility and concentration, the evaluation method of Salamon (1976) was used. The $\mathrm{pH}$ of the fresh semen was measured with a Duotest pH 5.0-8.0 (Macherey-Nagel, Düren, Germany) for all breeds.

The diluent (Tris) was warmed to $38^{\circ} \mathrm{C}$ before use. After that, the fresh ejaculate was diluted in one step; the amount of diluent added depended upon semen density. Before the ejaculation, glycerine and egg yolk were added to the base solution, prepared fresh each day. The components of the diluent were: Tris/hydroxymethyl-amino-methane: $3.63 \mathrm{~g}$, fructose: $0.50 \mathrm{~g}$, citric acid: $1.99 \mathrm{~g}$, double-distilled water: $100 \mathrm{ml}$, glycerine: $5 \mathrm{ml}$, egg yolk: $15 \mathrm{ml}$. Linco-Spectin (Pharmacia, Puurs, Belgium), Tylosin (Medica Gmbh, Germany) and Vetrigent 5 (Ceva Sante Animale, Libourne, France) were used as antibiotics. The diluted semen was then cooled to $4^{\circ} \mathrm{C}$ and aspirated into $0.25 \mathrm{ml}$ plastic straws at a constant temperature and deep frozen after equilibration for a minimum of $2 \mathrm{~h}$. One objective of the experiment was to obtain a realistic picture about the freezability of the tested rams' semen both by season and by breed at the farm level. Therefore, all samples in which mass motility was observed were deep-frozen even if they were of very poor quality.

On each occasion, one plastic straw of the frozen sperm was thawed in a $40^{\circ} \mathrm{C}$ water bath for 10-12 $\mathrm{s}$ and evaluated, while another one was tested for heat resistance in a water bath at $46^{\circ} \mathrm{C}$ for $1 \mathrm{~h}$ and then examined. The evaluation was performed using an Olympus BX61 microscope and a DP71 camera (both Olympus, Tokio, Japan).

Scrotal circumference was measured according to the method of Mucsi (1997) at the widest part of the testis with a paper tape measure in each season.

The descriptive statistical evaluation of the data was carried out using SPSS for Windows 11.0 (SPSS Inc. Chicago, IL, USA) in addition to the descriptive method. The different breeds were described per season with means and standard errors of the mean.

\section{Results}

\section{Examination of fresh semen}

The highest semen volume was produced by lle de France breed in the autumn $(1.75 \mathrm{ml})$, in the winter $(1.89 \mathrm{ml})$ and in the spring $(1.75 \mathrm{ml})$. The second one was the Tsigai in the summer. The lowest volume of semen was produced by Suffolk in the autumn $(1.33 \mathrm{ml})$, in the winter $(1.36 \mathrm{ml})$ and in the summer $(1.0 \mathrm{ml})$ and by Barbados Blackbelly in the spring $(1.19 \mathrm{ml})$. Attention should be given to the continuous and dramatic decrease in the semen volume of the breed Barbados Blackbelly.

The semen density of Prolific Merino was by far the highest and most balanced. The semen was the most dense in the winter and most diluted in the autumn for the most breeds. An exception was the semen of Suffolk rams which was very watery (2.35) in the summer.

Regarding the mass motility and percent motility of semen, the highest values were measured in the winter for the breeds Tsigai, lle de France and Suffolk, which were slightly reduced in the spring and at the lowest point in the summer. Except for two breeds (Barbados Blackbelly and Babolna Tetra), the mass motility was weaker in the summer. Mass motility was the best in semen collected in the autumn from Awassi, Prolific Merino and Babolna tetra. The same trend was observed for mass motility and percent motility. 
The $p H$ of the ejaculate of the studied breeds ranged between 7.0 and 7.7, on average, with little deviation. There were two extreme values: 6.6 for Tsigai Rams in the autumn with high deviation and the spring average of Babolna Tetra, 7.9.

\section{Examination of the effect of cryopreservation}

Ram sperms show great diversity in their response to freeze-thawing both per season and per breed. The post-freezing survival rate of sperm from Awassi rams was by far the highest in three seasons, but this did not apply to these parameters recorded in the summer. The second best thawing result was measured in Prolific Merino in the winter, in the spring and in the summer. It could be observed that the semen samples collected from Barbados, Suffolk, Prolific Merino and Bábolna Tetra in the autumn had the lowest tolerance to freezing.

The freezability of semen from Barbados Blackbelly, Tsigai and Suffolk rams was the best in the winter. Freezing of semen was the most successful in the spring for three breeds (Awassi, Bábolna Tetra and Prolific Merino).

Ram sperm were tested for heat resistance after freeze-thawing. The Awassi breed showed outstandingly good results except for the summer, when it gave the worst result for heat resistance among all the breeds. Out of the 7 studied breeds, 6 (Awassi, Barbados Blackbelly, Babolna Tetra, Tsigai, Suffolk and Prolific Merino) gave the highest values in the winter or in the spring with large individual differences. The weakest breeds regarding the heat resistance test were lle de France in the winter and Barbados Blackbelly in the spring.

\section{Variation in scrotal circumference according to season and breed}

The same trend was observed in the seasonal variation of scrotal circumference in half of the breeds (Awassi, Babolna Tetra, Barbados Blackbelly and Tsigai) with a winter or spring minimum and a summer or autumn maximum (Figure 1).

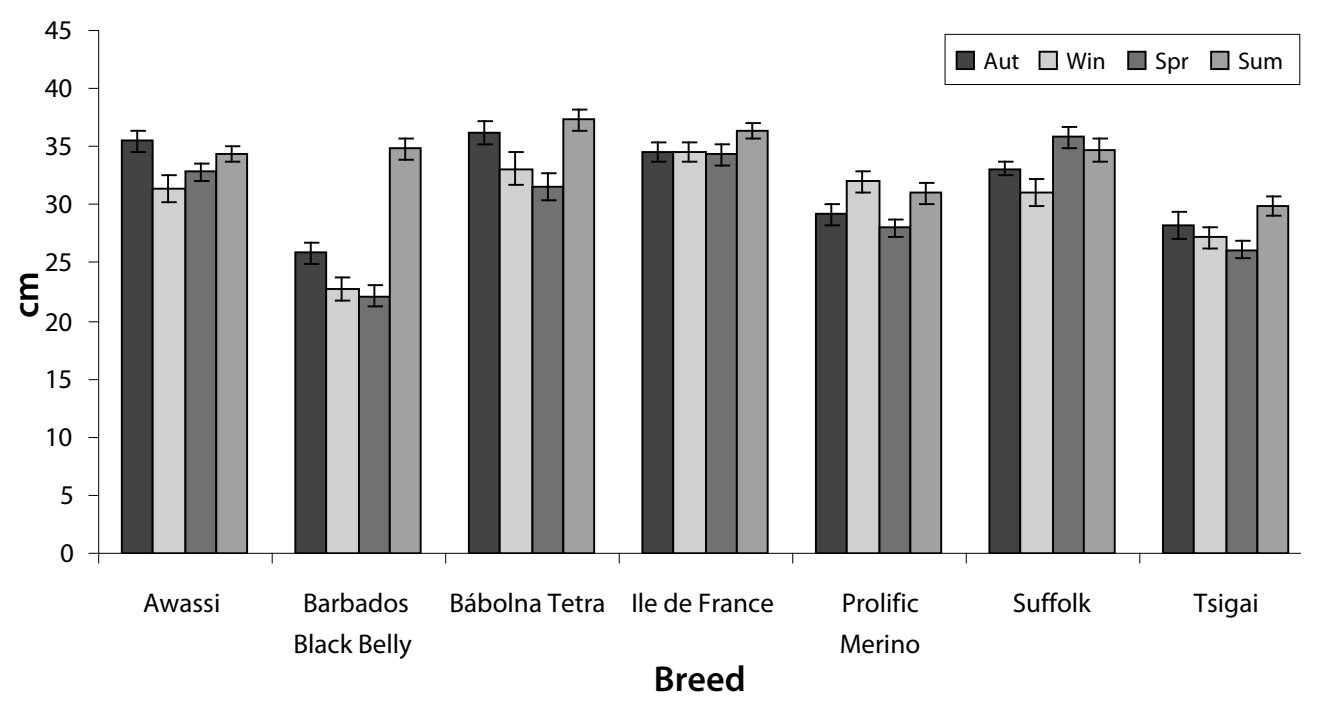

Figure 1

Means and standard errors of scrotal circumference per breed and season 
The largest scrotal circumference was measured in the autumn for Awassi $(35.5 \mathrm{~cm})$, in the spring for Suffolk $(35.8 \mathrm{~cm})$ and in the winter for Prolific Merino $(32 \mathrm{~cm})$. For the other studied breeds, the maximum value was measured in the summer. During the study period, the smallest scrotal circumferences were measured in Barbados Blackbelly except for in the summer, when it increased by $12.5 \mathrm{~cm}$.

\section{Discussion}

\section{Examination of fresh semen}

During the last 60 years several authors (Ivanov 1951, Salamon 1976, Menchaca et al. 2005, Safdarian et al. 2006) have given an interval for the average volume of ram semen with 0.5$2 \mathrm{ml}$ and it was confirmed by our results as well with a slight difference in their breed and season. The best semen production of lle de France with the highest value in the autumn $(1.75 \mathrm{ml})$, in the winter $(1.89 \mathrm{ml})$ and in the spring $(1.75 \mathrm{ml})$. The lowest volume of semen was produced by Suffolk rams in the autumn $(1.33 \mathrm{ml})$, in the winter $(1.36 \mathrm{ml})$ and in the summer (1.0 ml).

The density of ram semen is 3 billion/ml on average according to a Hungarian author (Gergátz 2007). Based on the season average of the studied breeds, we obtained 3.14 billion/ $\mathrm{ml}$ in the autumn, 3.57 billion/ml in the winter, $3.5 \mathrm{billion} / \mathrm{ml}$ in the spring and $3.34 \mathrm{billion} / \mathrm{ml}$ in the summer. Nowakowski \& Cwikla (1994) found that the quality of semen was the best in March in Polish Merino rams (higher motility value and higher density).

According to Salamon (1976) and Gergátz (2007), in a good-quality ejaculate, at least $70 \%$ of the spermatozoa should perform vivid, flashing forward motion.

For the breeds Tsigai, Ile de France and Suffolk, both values were the highest in the winter, then were slightly reduced in the spring and were lowest in the summer. The worst results were obtained from Suffolk rams in three seasons, and the percent motility of fresh ejaculates was $37 \%$ in the summer.

The $\mathrm{pH}$ of the studied breeds varied between 7.0 and 7.7 on average with small deviations. Different values were measured for Tsigai in the autumn with $\mathrm{pH} 6.6$ with large deviations, and the spring average of the Babolna Tetra breed was 7.9. These values are parallel with literature datas (Látits \& Sarlós 2006, Wierzbowski 1996)

\section{Examination of the effect of cryopreservation}

Ram semen is very sensitive to cryopreservation (Látits \& Sarlós 2006), which is also influenced by the season in addition to the significant differences between individuals. Sperm collected and frozen in the autumn have better conception rates compared to sperm collected in the spring (Mucsi 1997). Our results confirmed it only in case of lle de France.

\section{Variation in scrotal circumference according to season and breed}

The growth of the testis starts before the mating season during the long days in June and July (Horváth 1983). Mickelsen et al. (1981) studied the impact of season on scrotal circumference for 10 Suffolk rams and found that the average scrotal circumference was the largest in October at $36 \mathrm{~cm}$. We found the highest value $(35,8 \mathrm{~cm})$ in spring for the same breed. Kafi et 
al. (2004) found the lowest value for scrotal circumference in the winter (average $31.1 \mathrm{~cm}$ ) and the highest value in the autumn $(33.3 \mathrm{~cm})$ for Karakul rams, as we got for an other fat-tailed breed, Awassi. For the other studied breeds the largest scrotal circumference was measured in the summer. The reason for this is the approach of the main mating season; spermiogenesis takes 49 days in rams, followed by a post-maturity stage of 11-14 days in the epididymis. This means that sperm developing from the spermatogonium will appear in the ejaculate 60-63 days later under medium mating intensity (Mucsi 1997, Gergátz 2007).

\section{Acknowledgements}

The authors would like to thank the farmers and workers at the UD Experimental Farm for their help and collaboration with taking samples. This work was financed by GAK- ALAP100019/2004.

\section{References}

Dacheux JL, Pisselet C, Blanc MR, Hochereau-de-Reviers MT, Courot M (1981) Seasonal variations in rete testis fluid secretion and sperm production in different breeds of ram. J Reprod Fertil 61, 363-371

D'Alessandro AG, Martemucci G (2003) Evaluation of seasonal variations of semen freezability in Leccese ram. Anim Reprod Sci 79, 93-102

Gergátz E (2007) [Artificial insemination of sheep]. In: Pécsi T (ed) [Artificial insemination of domestic mammals]. Mezőgazda Press, Budapest, Hungary, 335-367 [in Hungarian]

Horváth M (1983) [Andrology of rams]. In: Becze J (ed) [Reproduction of male animals]. Mezőgazdasági Press, Budapest, Hungary, 192-193 [in Hungarian]

Ivanov MF (ed) (1951) [Sheep breeding]. Mezőgazdasági Press. Budapest, Hungary [in Hungarian]

Januskauskas A, Johannisson A, Söderquist L, Rodriguez-Martinez H (2000) Assessment of sperm characteristics post-thaw and response to calcium ionophore in relation to fertility in Swedish dairy Al bulls. Theriogenology 53, 859-875

Kafi M, Safdarian M, Hashemi M (2004) Seasonal variation in semen characteristics, scrotal circumference and libido of Persian Karakul rams. Small Rumin Res 53, 133-139

Látits Gy, Sarlós P (2006) [Reproduction of sheep]. In: Jávor A, Kukovics S, Molnár Gy (eds): [Sheep breeding from $A$ to $Z$ ]. Mezőgazda Press, Budapest, Hungary, 179-207 [in Hungarian]

Menchaca A, Pinczak A, Queirolo D (2005) Storage of ram semen at $5^{\circ} \mathrm{C}$ : effects of preservation period and timed artificial insemination on pregnancy rate in ewes. Anim Reprod 2, 195-198

Mickelsen WD, Paisley LG, Dahmen JJ (1981) The effect of season on the scrotal circumference and sperm motility and morphology in rams. Theriogenology 16, 45-51

Mickelsen WD, Paisley LG, Dahmen JJ (1982) Seasonal variations in scrotal circumference, sperm quality, and sexual ability in rams. J Am Vet Med Assoc 181, 376-380

Mucsi I (ed.) (1997) [Sheep breeding and keeping]. Mezőgazda Press, Budapest, HU [in Hungarian]

Nowakowski P, Cwikla A (1994) Seasonal variation in testes size in Polish Merino rams and its relationship to reproductive performance in spring. Theriogenology $42,613-622$

Pelletier J, Chemineau P, Delgadillo JA (1988) Seasonality of sexual activity and its photoperiodic control in the adult ram and he-goat. Proceedings of the 11th Int. Congress on Animal Reproduction and Artificial Insemination, Belfield Campus, University College Dublin, Ireland, 211-219

Safdarian M, Hashemi M, Kafi M (2006) Seasonal changes in semen quality, scrotal circumference and blood testosterone level of Persian Karakul rams. Book of Abstracts of the 57th Annual Meeting of the European Association for Animal Production (EAAP), Antalya, Turkey, 203 
Salamon S (1976) Artificial Insemination of Sheep. Publicity Press, Chippendale, Australia

Salamon S, Maxwell WMC (2000) Storage of ram semen. Anim Reprod Sci 62, 77-111

Söderquist L, Rodriguez-Martinez H, Janson L (1991) Post-thaw motility, ATP content and cytochrome C oxidase activity of A. I. bull spermatozoa in relation to fertility. J Vet Med A 38, 165-174

Wierzbowski S (1996) [Andrology]. Wydawnichtwo Platan Kryspinów, Kraków, Poland [in Polish]

Zhang BR, Larsson B, Lundeheim N, Rodriguez-Martinez H (1998) Sperm characteristics and zona pellucida binding in relation to field fertility of frozen-thawed semen from dairy Al bulls. Int J Androl 21, 207-216 